\title{
Serological investigations in children with colonized Spitz-Holter valves
}

\author{
R. BAYSTON \\ From the Department of Pathology, Children's Hospital, Sheffield
}

SYNOPSIS It has been found that children with hydrocephalus, whose Spitz-Holter valves are colonized with Staph. albus, have an antibody to this organism in their serum. Children without i colonized shunts have little or no such antibody. A test for this antibody is described, and its use in such cases is discussed.

Colonization with organisms of the Staph. albus group is a common and troublesome complication of the treatment of hydrocephalus with Spitz-Holter valves. The most successful method of eradicating the resulting bacteraemia is removal of the shunt system (Callaghan, Cohen, and Stewart, 1961; Bruce, Lorber, Sheddon, and Zachary, 1963; Luthardt, 1970; Nicholas, Kamal, and Eckstein, 1970). This may be replaced at a later date, but scarring of the neck veins limits the number of revisions.

The laboratory diagnosis of colonized shunt is made by isolation of the offending organism from the blood, usually after pumping the valve. However, organisms of the Staph. albus group can be found on the body surfaces (Holt, 1969) and are not infrequently isolated as contaminants from blood cultures, and, in some cases, cerebrospinal fluid (CSF). If such an organism is isolated from a blood culture taken from a patient who is suspected of having a colonized shunt, the problem arises as to whether the organism is a contaminant or whether it is a pathogen.

Several attempts have been made to solve this problem. Typing of the organisms according to their biochemical characteristics shows little or no difference between those strains isolated from the skin and those responsible for shunt colonization (Holt, 1969).

The methods so far used give information about the organism involved, but this information may not be very relevant to the patient's condition. It was felt that if such an organism were present as a pathogen, the patient should respond to its continued presence by producing antibodies specifically reactive against it (Bayston, 1971). This, of course, ought not to be so if the organism were present as a contaminant. A test was devised to investigate this idea.

\section{Production of the Antigen}

Using a strain of Staph. albus of type SIIA, a type N commonly found in colonized shunts, and a serum from a patient known to have a colonized shunt, tests for antibody-antigen reaction were carried out. Live organisms, those treated with trypsin, pepsin, and $0.2 \mathrm{~N}$ hydrochloric acid, and their extracts, auto- $\frac{\mathbb{Q}}{\circ}$ claved cells, and culture filtrates were used in a $\underset{F}{\rightleftharpoons}$ variety of serological tests. Results of these tests showed that a preparation consisting of autoclaved cells gave good results in a simple agglutination test. This test was refined and the antigen concentration adjusted to give an endpoint which is easily read and which is reproducible.

A larger number of other strains and subtypes of Staph. albus and several strains of Staph. pyogenes $\delta$ were then investigated for agglutination in the immune serum after autoclaving and it was found 을 that, almost without exception, all strains of Staph. $>$ albus tested gave positive results, all the strains of Staph. pyogenes giving negative results. The only $\bar{N}$ exceptions were two strains of Staph. albus subtypes SIIP and SVI. These two particular strains were $\mathbb{O}$ atypical in that other strains of these subtypes $\underset{\mathrm{C}}{N}$ agglutinated normally in immune serum. Both strains have not subsequently been found in this 0 hospital. The antigen prepared by autoclaving $\frac{C}{\Phi}$ organisms of subtype SIIA appears to be common to virtually all strains of Staph. albus.

\section{Test Procedure}

1 ANTIGEN

A strain of Staph. albus SIIA is grown on blood agar 
at $37^{\circ} \mathrm{C}$ for two days. The growth is then scraped off, washed twice in saline, and centrifuged. The washed cells are then resuspended in approximately $1 \mathrm{ml}$ of saline and autoclaved for one hour at $15 \mathrm{lb} \mathrm{sq}$ in. $\left(121^{\circ} \mathrm{C}\right)$. Autoclaving at a higher temperature or for a longer period depresses the activity of the antigen. After cooling, the cells are again washed in saline. A dense suspension is used in the slide agglutination test. For the titration the suspension is diluted to give a suspension of Browne's tube opacity 10 (approximately 600000000 organisms $/ \mathrm{ml}$ ).

\section{PATIENT'S SERUM}

Blood may be taken by finger prick into a $0.4 \mathrm{ml}$ plastic tube or by venepuncture. After clotting has taken place the serum is separated.

\section{SCREENING TEST}

The patient's serum is first tested by slide agglutination. If this is negative, there is no need to proceed. If any agglutination occurs, a titration is carried out.

\section{TITRATION}

This step is carried out in WHO trays. One volume is equivalent to $0.2 \mathrm{ml}$.

Using an automatic pipette, 2 volumes of saline are added to the first well and 1 volume to each of the rest: $0.04 \mathrm{ml}$ of patient's serum is added to the first well, and after thorough mixing, one volume is 'double diluted' along the row. One volume of antigen, prepared as above, is added to each well, to give the final dilutions ranging from $1 / 20$ to $1 / 10240$. The tray is shaken gently to mix and incubated at $37^{\circ} \mathrm{C}$ for one hour, after which it is refrigerated overnight. The highest dilution giving $100 \%$ agglutination is taken as the endpoint.

\section{Application of the Test}

Using the procedure described above, samples of serum from 300 normal children of various ages up to 12 years were examined for antibody to Staph. albus antigen (see Table). Similarly, serum from 200 children with Spitz-Holter valves, but with no sign of colonization, were tested along with specimens from

\begin{tabular}{|c|c|c|c|c|}
\hline & & No. Tested & No. Positive & $\begin{array}{l}\text { Range of } \\
\text { Titres in } \\
\text { Positives }\end{array}$ \\
\hline \multirow{2}{*}{$\begin{array}{l}\text { Children not } \\
\text { having } \\
\text { colonized } \\
\text { shunts }\end{array}$} & $\int_{\text {Normal }}$ & 300 & 5 & $<1 / 20-1 / 40$ \\
\hline & $\left\{\begin{array}{l}\text { Spina } \\
\text { bifida }\end{array}\right.$ & 200 & 15 & $<1 / 20-1 / 80$ \\
\hline \multicolumn{2}{|c|}{$\begin{array}{l}\text { Children with colonized } \\
\text { shunts }\end{array}$} & 9 & 9 & $1 / 320-1 / 5120$ \\
\hline
\end{tabular}

Table Results of tests several children whose Spitz-Holter shunts were colonized with Staph. albus. Among the children in the first two groups were a few who had superficial infections with both Staph. pyogenes and Staph. albus. The results are shown in the Table. It may be seen that the small number of sera in the two uninfected groups which gave a positive slide test showed a low titre, but the sera from the group with colonized shunts gave very high titres. The children with colonized shunts had the usual symptoms suggestive of this condition, ie, intermittent pyrexia, malaise, splenomegaly, anaemia, etc, and all had positive blood cultures, Staph. albus being isolated on more than one occasion. In all cases the shunt was removed and examined bacteriologically, and Staph. albus was isolated from inside the valve chamber.

As this test promised to be useful, it was carried out routinely on all children who had shunts inserted or revised. Blood was taken just before or immediately after operation. The results were invariably negative or insignificant. These children had no signs of colonization of their shunts. The results were compared with others obtained during any pyrexial episodes or suspected colonizations which occurred later.

Sera were also investigated from patients whose shunts had been in place for a long period (over one year), and who were seen clinically with intermittent pyrexia or suspected blocked valve. Many of these also gave insignificant results, and in these cases the symptoms were subsequently found to be due to some cause other than colonization, such as urinary tract or respiratory tract infections, or blocked lower catheters. However, a few showed elevated titres, and four cases of colonized shunt were detected or confirmed in this way. In one case where a blocked lower catheter was found at operation the patient's serum showed a Staph. albus antibody titre of 1/640 and a blood culture grew Staph. albus. It is possible that this patient's shunt was both blocked and colonized.

\section{Discussion}

Antibodies to Staph. albus were sought in the sera of patients with suspected shunt colonization for several reasons. This group of organisms is mainly responsible for such colonization, other organisms occurring far less commonly and usually producing different symptoms. Thus, if no Staph. albus agglutinins are found in the serum from a suspected case, it seems that it is extremely unlikely that the patient's condition is due to colonization with Staph. albus. As infection with organisms other than Staph. albus usually gives a different clinical picture, a negative Staph. albus antibody test may be particularly useful 
in deciding whether colonization of the shunt has occurred at all.

Another reason for investigating the use of serological tests in this situation was that it was felt that a more reliable and directly applicable test should be available. It has been found, as has been shown, that serological tests on sera from patients suspected of having colonized shunts gave results which are relatively simple to obtain, are quickly available, and are easily interpreted.

Three patients included in this study, who have had their colonized shunts removed, had blood taken at weekly intervals afterwards to see how long the previously high antibody titre would take to return to normal. All remained high for at least two months after the shunt was removed, and then began to fall very slowly. It is not yet known whether a significant antibody response is provoked by meningitis due to Staph. albus, without septicaemia in children without shunts, but three children who had ventriculitis in the absence of septicaemia produced no agglutinating antibody.

Since this investigation was begun, three cases of 'shunt nephritis' (Black, Challacombe, and Ockenden, 1965; Stickler, Shin, Burke, Halley, Miller, and Segar, 1968; Stauffer, 1970) have been investigated at this hospital. In these cases the demonstration of a high antibody titre to Staph. albus antigen was very useful in making the diagnosis.

It would be of interest to investigate the possibility of using this test to aid diagnosis in postcardiotomy patients who develop signs of endocarditis, and indeed in any situation where Staph. albus is found to be present yet difficult to incriminate.

My thanks are due to Dr J. L. Emery, consultant pathologist to this hospital, for valuable advice during the preparation of this paper, and to Miss Helen Armstrong for typing the manuscript. The patients referred to were under the care of $\mathrm{Dr} J$. Lorber and Mr R. B. Zachary. One of the children with shunt nephritis was under the care of Dr M. W. Moncrieff at Derby Children's Hospital.

\section{References}

Bayston, R. (1971). Serological indication of Staphylococcus albus infection in children with colonised shunts. Develop. Med. Child Neurol., 13, Suppl. 25, 135-136.

Black, J. A., Challacombe, D. N., and Ockenden, B. G. (1965). Nephrotic syndrome associated with bacteraemia after shun operations for hydrocephalus. Lancet, 2, 921-924.

Bruce, A. M., Lorber, J., Sheddon, W. I. H., and Zachary, R. B. (1963). Persistent bacteraemia following ventriculo-caval shunt operations for hydrocephalus in infants. Develop. Med. Child Neurol., 5, 461-470.

Callaghan, R. P., Cohen, S. J., and Stewart, G. T. (1961). Septicaemia due to colonization of Spitz-Holter valves by staphylococci: five cases treated with methicillin. Brit. med. J., 1, 860-863.

Holt, R. (1969). The classification of staphylococci from colonized ventriculo-atrial shunts. J. clin. Path., 22, 475-482.

Luthardt, T. (1970). Bacterial infections in ventriculo auricular shunt systems. Develop. Med. Child Neurol., 12, Suppl. 22, 105-109.

Nicholas, J. L., Kamal, I. M., and Eckstein, H. B. (1970). Immediate shunt replacement in the treatment of bacterial colonization of Holter valves. Develop. Med. Child Neurol., 12, Suppl. 22, 110-113.

Stauffer, U. G. (1970). Shunt nephritis: diffuse-glomerulonephritis complicating ventriculo atrial shunts. Develop. Med. Child. Neurol., 12, Suppl. 22, 161-164.

Stickler, G. B., Shin, M. H., Burke, E. C., Holley, K. E., Miller, R. H., and Segar, W. E. (1968). Diffuse glomerulonephritis associated with infected ventriculo atrial shunt. New Engl. J. Med., 279, 1077-1082. 